\title{
Minor Salivary Gland Adenoid Cystic Carcinoma
}

National Cancer Institute

\section{Source}

National Cancer Institute. Minor Salivary Gland Adenoid Cystic Carcinoma. NCI

Thesaurus. Code C5936.

An aggressive carcinoma that arises from the minor salivary glands. It is characterized by the presence of malignant epithelial and myoepithelial cells forming cribriform, tubular, and solid patterns. It usually presents as a slow growing mass. 